DOI: $10.24234 /$ wisdom.v15i2.335

Yulia VORONTSOVA, Artur ARAKELYAN, Vladimir BARANOV

\title{
SMART TECHNOLOGIES: UNIQUE OPPORTUNITIES OR THE GLOBAL CHALLENGES OF TRANSHUMANISM
}

\begin{abstract}
The article is devoted to issues related to the creation and use of innovative breakthrough technologies. At the present stage of transhumanistic concept implementation, it is necessary to consider its reflection in various fields of scientific knowledge. This concept has been recently arousing genuine interest both in its direction and in its contradictions. Today, there is a discussion around this, which allows us to evaluate all the "pros" and "cons" of a transhumanistic idea implementation, which requires improving the physical condition of a person by using the most advanced technologies, among which an important place is taken by biotechnologies, artificial intelligence and other Smart technologies. Their use generates contextual social, economic, and political problems. Therefore, the authors propose an interdisciplinary approach to assess various types of transhumanism challenges, taking into account the use of their unique capabilities while minimizing the risks associated with this. This aspect is proposed to be considered using the mechanism that forms the risk expanse and tools for working with it.
\end{abstract}

Keywords: artificial intelligence, challenges, digital economy, interdisciplinary approach, risk zone, risks, smart technologies, technological breakthrough, transhumanism, transhumanistic expanse.

\section{Introduction}

In the modern global world, to implement the transhumanistic concept, modern science provides an opportunity to improve/strengthen the physical features of a person, thus minimizing his infirmities. This includes such disciplines as physics, biology, chemistry, IT technology, genetic engineering, nanotechnology, and others. (Terrones Rodriguez, 2019). The progressive technical development started in the twentieth century (human flight into Space, creation of super-powerful weapons, etc.), but the technological breakthrough in the XXI century allows the transhumanist concept to be fully realized. Furthermore, this is not a matter of long-term prospects. Nowadays, human nature is boiled down to its empirically observable qualities, to the biological and mechanistic vision of human. The transhumanistic vision denies the classical prospect of human nature and considers it as a permanent self-construction, using science and technology as allies (Vorontsova \& Postigo Solana, 2019, p. 61). Today, there are several directions in which humanity is moving; these are everything related to the creation of artificial intelligence and everything related to biology, including the field of medicine. In the end, these two 
paths must unite to form a single transhumanistic expanse.

Transhumanism opposes to the Christian position, since it is based on the search for opportunities of unlimited improvements, challenging ageing and death by using the achievements of science and technology that provide the tools necessary to achieve these goals (Diéguez, 2017). And opportunities already exist for expanding human potential: according to one scenario, this is a significant improvement in human conditions for life, according to another, it is possible to face severe risks in abuse of innovative technologies, which will lead to a critical risk, and then, to a disaster (Bajo Sanjuán \& Villagra García, 2017, pp. 52-55).

The progress is a change, but not every change is related to the progress. It is necessary to focus on responsible decisions that take into account the moral aspect, take seriously the opportunities provided by new technologies, as well as the risks associated with their implementation, thus, taking care of future generations ("Humanity", 2018).

Forming the Interdisciplinary

Approach to Assess the Challenges of Transhumanism

To fully understand the processes taking place in the modern world based on the implementation of the transhumanism concept, it is necessary to imagine the interdisciplinary expanse covered by it. First of all, it is undoubtedly philosophy, starting from Aristotle and ending with modern thinkers such as Anders Sandberg, Julian Savulescu and others. It is necessary to understand that mankind's search for immortality is not new. Transhumanism is just a "new arena of old controversy" since there is a close intercon- nection between transhumanism and the most ancient genetic techniques (Postigo Solana, 2018, p. 1). This refers us to a field like genetic engineering, which is directly related to biology. However, transhumanism creates a new atmosphere against the background of the modern scientists' attention from different fields of knowledge to the problems of creating artificial intelligence, which allows us to talk about the participation of such sciences as physics and IT technologies. This list can be expanded, including there some particular areas of basic disciplines. In the figure, the authors present the interconnections and interdependencies of the transhumanism's challenges. Key factors were formed based on the materials of the International forum "Transhumanism. Anthropological, ethical, legal and theological challenges", that took place from 29/05/2019 till 31/05/2019 in Madrid, Spain (University Pontificia Comillas ICAI-ICADE) ${ }^{1}$. Thus, the transhumanistic phenomenon can be

See the Materials of the International Forum "Transhumanism. Anthropological, Ethical, Legal and Theological Challenges", University Pontificia Comillas ICAIICADE, Madrid, Spain, 29-31 of May 2019 Retrieved from: https://yandex.ru/video/preview/?filmId=100231$46014865795432 \&$ from $=$ tabbar\&parentreqid $=1594794$ 055023801-1779256897575601315600143-production-app-host-sas-web-yp-139\&text=transhumanismo+icai-icade; https://yandex.ru/video/preview/?filmId=794$62548673926059 \&$ from $=$ tabbar\&parent-reqid $=15947$ 94532098373-106221217661670828800228-production-app-host-sas-web-yp-117\&text=transhumanismo+icai-icade+29/05/2019; https://yandex.ru/video/preview? filmId $=4276874936762618323 \&$ text=transhumanis mo\%20icaiicade $\% 2029 \% 2 F 05 \% 2 F 2019 \% 203$ parte\&path=wizard\&parent-reqid=1594794682187396-819078097203980102100215-production-app-host-man-web-yp-249\&redircnt=1594794741.1; https://yandex.ru/video/preview?filmId $=15083005774336285764 \&$ text=transhumanismo $\% 20$ icaiicade $\% 2029 \% 2 F 05 \% 2 F 20$ $19 \% 203$ parte \&path=wizard\&parent-reqid $=15947946$ 82187396-819078097203980102100215-productionapp-host-man-web-yp-249\&redircnt=1594794831.1; https://yandex.ru/video/preview?filmId=4874233304479197765\&text=Transhumanismo. $\% 202 \% \mathrm{C} 2 \% \mathrm{BA}-$ \%20parte.\%20Sesi $\%$ C3\%B3n\%20de $\% 20$ Tarde. $\% 20$ $30 \% 2 \mathrm{~F} 05 \% 2 \mathrm{~F} 2019 \&$ path=wizard \&parent-reqid $=159$ 4794983393429-886537662298786367600292-production-app-host-vla-web-yp-23\&redircnt=1594794992.1; 
considered as a nascent object of research (Diéguez, 2018). Returning to the philosophy, it can be stated that transhumanism has formed two strictly differentiated positions: bioconservative and bioprogressive. The conservative line is taken by those who look at improvement technologies with distrust, relating to this based on pre- caution's principle. Opposite the bioconservatives are those, who advocate technological improvements that are driven by transhumanism, achieving the maximum unlimited improvement that can be realized due to the impressive opportunities provided by biotechnology.

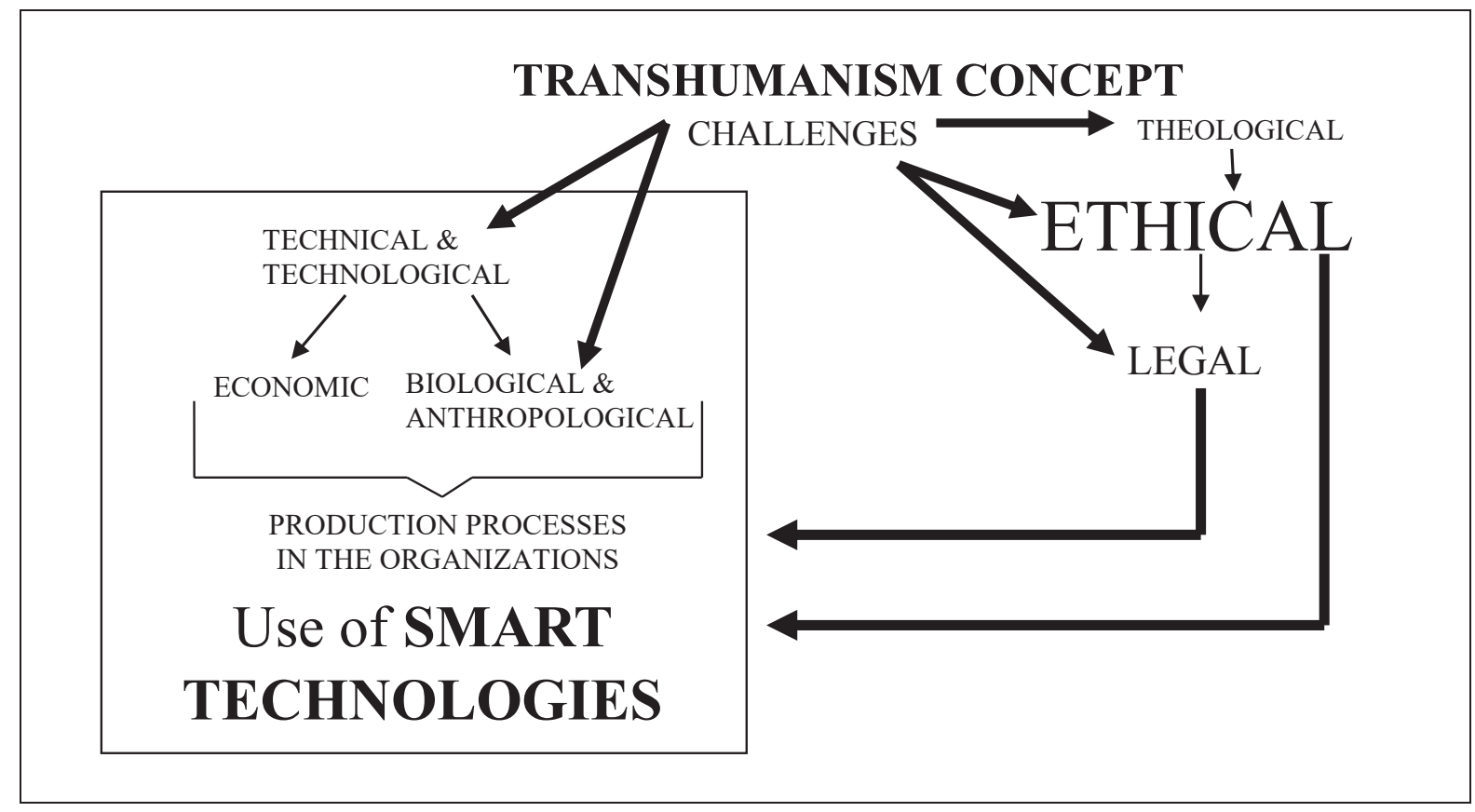

Figure: The Place of SMART Technologies as a part of the Interdisciplinary Approach in Assessing the Challenges of Transhumanism (created by the authors based on the materials of the International forum

"Transhumanism. Anthropological, ethical, legal and theological challenges", University Pontificia Comillas ICAI-ICADE, Madrid, Spain, 29-31 of May, 2019).

The figure shows the concept of the interdisciplinary approach, based on a bioconservative position that takes into account not only the natural scientific aspect but also includes a humanitar-

https://yandex.ru/video/preview? filmId=2866301257069101515\&text=Transhumanismo. $\% 203 \% \mathrm{C} 2 \% \mathrm{BA} \% 20$ parte. $\%$ 20Sesi $\%$ C3 $\%$ B3n $\% 20$ de $\% 20$ Tarde. $\% 2030 \% 2 F 05 \% 2 F 20-$ 19\&path=wizard\&parent-reqid=1594795072442218-1586376026118072235000251-production-app-host-vla-web-yp-73\&redircnt $=1594795083.1$;

https://yandex.ru/video/preview?filmId $=889252140979998$ 8457\&text=Transhumanismo. $\% 203 \% \mathrm{C} 2 \% \mathrm{BA} \% 20$ parte. $\%$ 20Sesi $\%$ C3\%B3n $\% 20$ de $\% 20$ Tarde. $\% 2031 \% 2$ F05\%2F 201 9\&path=wizard\&parent-reqid $=1594795180476785-32535-$ $47 \quad 52 \quad 597855056100216$-prestable-app-host-sas-web-yp164\&redircnt=1594795186.1. ian component, such as ethics and theology. Ethics, combined with such basic disciplines as biology and chemistry, created a scientific field called bioethics, that also studies issues related to the transhumanism: its foundations, direction, and possible consequences for the modern world including the policy of using methods of manipulating species that represent various forms of genetic intervention.

However, science is moving faster than our understanding of "morality" (Sandel, 2016, pp. 42-49). Therefore, in the beginning, we need to estimate some opportunities that innovative tech- 
nologies give to the world, which, from the first view, can be used separately from the transhumanistic concept, naming the process of their creation and implementation as a digital economy.

\section{The Unique Opportunities of Smart Technologies}

Smart technologies play an important role in the digital economy. They make it possible to free up the employee's time to solve other important company's goals. Moreover, they can also be used to optimize the employee's wage, social insurance and social security contributions, office rentals, because people can work remotely, and so on. However, it is interesting to consider the unique opportunities of using Smart technologies on a global scale.

As it was mentioned above, creation and use of innovative technologies go in two directions. The authors focus on the direction that tends to the creation of artificial intelligence in the global digital space. We are talking about complex systems that give more opportunities to various structures for self-organization, and help support unlimited expansion, for both organizations and States, taking into account the features and difficulties throughout the Universe (Goldin \& Mariathasan, 2014, pp. 186-194).

Advanced Smart technologies have a tendency to be "clean" and efficient since it becomes possible to reduce resources' needs virtualizing some tools significantly. Low-level control of matter allows efficient processing of it, and biotechnology can be considered as a "green" technology. Besides, various cost-effective systems allow to distribute and use dispersed energy sources. In the long term (Feltrero, 2018), the same Smart technologies are supposed to use to provide opportunities for exploring new and significant areas (for example, space or other new innovative technologies). In particular, the creation of factories in Space and managing them from Earth, thus cleaning its surface and increasing the environmental level.

Using robotics will allow businesses to work without considering the human resource at the same scale, and this is real cost savings. However, these innovations will change the picture of the world, which will lead to such risks as unemployment, reducing income levels and, as a result, reducing their consumer activity. The circle is complete. But we will consider risks a bit later.

Nowadays, such science as bionics is developing. Some scientists, trying to create artificial intelligence, talk about downloading/uploading the mind and are ready to go for its direct scanning and simulation it as a software (Sandberg, 2012). Nanotechnology will move forward by using more traditional low-level chemical simulators since the need for interpretation of simulations grows. To do this, there are many ways to mathematically describe complex systems modelled in such a way in order to predict the most efficient use of complex models. However, there is no specific "working" approach. In parallel, many alternative scenarios need to be worked out, which will require a dynamic, upward process, rather than using a single specific tool.

\section{Formation of a Mechanism to Work with the Risk Expanse}

Any activity in the competitive environment of the digital expanse has a high degree of uncertainty. Since this uncertainty is characterized by various factors, the digital risks generated by this uncertainty also have different forms (Armstrong, 
Bradshaw, Beckstead, \& Sandberg, 2015, pp. 1427). Smart technologies and their impact will create a risk-expanse where the danger of making an inadequate decision always exists in their practical use. If we model the "negative" results using risk parameters, this will allow us to outline the threats field, that will reflect the challenges of digitalization within the transhumanism trend. Forming the boundaries of this field, we can talk about risk zones (Yurchenco, \& Galyatkina, 2012, pp. 217-218). The value of possible limiting losses in each of the risk zones when using innovative technologies (Smart technologies include innovative biotechnologies, such as molecular nanotechnologies (Savulescu, 2012)) is characterized by the following:

- risk-free zone - a safe zone or zone that will be characterized by minimal profit from Smart technologies use;

- acceptable risk zone - using Smart technologies with an extended spectrum (while control in this area is reduced);

- critical risk zone - implementation of innovative technologies without considering the consequences of their use, which creates a threat to the life of alive organisms;

- catastrophic risk zone - a global catastrophe, the consequence of which is the de- struction of Earth life.

In the context of biotechnologies applying, the acceptable risk zone will be a safe intervention in the human body from the position "do no harm", and the critical risk zone - partial harm to human health, which can lead to a fatal result. The catastrophic risk zone will be characterized by the destruction of humanity as a species. The comparative analysis of the directions that form the transhumanist expanse by the risk zones of their use is presented in the Table.

For estimating risk and identifying its place in the relevant zone, it is proposed to use heuristic methods, such as Delphi method using a 10point scale. At the same time, the risk value should be considered not only in statics but also in dynamics in order to take timely and proactive measures for preventing risk increase and coming into the zones of critical and catastrophic risks. The speed of risk increase should be taken into account as well: a situation of a quick jump from the acceptable risk zone to the catastrophic risk zone is quite possible. Therefore, in case boundary values of risks are achieved, it is already necessary to take measures to reduce them, as well as to make forecasts to prevent "jumps" of risk indicators.

The Comparative Analysis of the Directions that Form the Transhumanist Expanse by the Risk Zones of Their Use.

\begin{tabular}{|c|c|c|}
\hline \multirow{2}{*}{$\begin{array}{l}\text { Risk } \\
\text { zones }\end{array}$} & \multicolumn{2}{|c|}{ Risk Characteristics and Measures to Minimize it } \\
\hline & Using Smart Technologies & Using Biotechnologies \\
\hline $\begin{array}{l}\text { risk- } \\
\text { free } \\
\text { zone } \\
(0-2)\end{array}$ & $\begin{array}{l}\text { Characterized by minimal profit from Smart tech- } \\
\text { nologies use due to the complexity of their im- } \\
\text { plementation and development. }\end{array}$ & $\begin{array}{l}\text { Applying biotechnologies without harm to the } \\
\text { moral and physical condition of a person. Form- } \\
\text { ing principles that allow to use innovative bio- } \\
\text { technologies. }\end{array}$ \\
\hline $\begin{array}{l}\text { accep- } \\
\text { table }\end{array}$ & $\begin{array}{l}\text { Getting into the acceptable risk zone is possible if } \\
\text { reduce control over the Smart technologies use }\end{array}$ & $\begin{array}{l}\text { Safe intervention in the human body from the } \\
\text { position "do no harm". When monitoring the }\end{array}$ \\
\hline
\end{tabular}




\begin{tabular}{|c|c|c|}
\hline $\begin{array}{l}\text { risk } \\
\text { zone } \\
(3-5)\end{array}$ & $\begin{array}{l}\text { with an extended spectrum of action. As a preven- } \\
\text { tive measure based on the predictive analysis it is } \\
\text { possible to apply intensified control over the pro- } \\
\text { cess. }\end{array}$ & $\begin{array}{l}\text { risk level from the use of biotechnologies in this } \\
\text { zone, it is necessary to follow the moral and eth- } \\
\text { ical principles formed by Bioethics. }\end{array}$ \\
\hline $\begin{array}{l}\text { critical } \\
\text { risk } \\
\text { zone } \\
(6-8)\end{array}$ & $\begin{array}{l}\text { Implementation of innovative technologies with- } \\
\text { out considering the consequences of their use, } \\
\text { which creates a threat to the life of alive organisms } \\
\text { and approaches opportunities' crisis of Smart } \\
\text { technologies use. Returning to the acceptable risk } \\
\text { zone is possible through high financial costs for } \\
\text { the compensation of consequences of a risky sit- } \\
\text { uation. }\end{array}$ & $\begin{array}{l}\text { Partial harm to human health that may lead to } \\
\text { death. Monitoring that actions for intervention in } \\
\text { the human body follow the principles developed } \\
\text { for the acceptable risk zone. Analysis of reasons } \\
\text { that caused deviations. }\end{array}$ \\
\hline $\begin{array}{l}\text { cata- } \\
\text { strophic } \\
\text { risk } \\
\text { zone } \\
(9-10)\end{array}$ & $\begin{array}{l}\text { The possibility of a global catastrophe that can } \\
\text { cause life destruction on Earth. Strict monitoring } \\
\text { the dynamics of the risk level within each zone (a } \\
\text { quality objective forecast), and in case of getting } \\
\text { into a catastrophic risk zone, applying, based on } \\
\text { predictive analysis, the tools, that are used in } \\
\text { emergencies. }\end{array}$ & $\begin{array}{l}\text { Characterized by the destruction of human as a } \\
\text { species. Strict monitoring the dynamics of the } \\
\text { risk level within each zone (a quality objective } \\
\text { forecast), and in case of getting into a cata- } \\
\text { strophic risk zone, applying, based on predictive } \\
\text { analysis, the tools, that are used in emergencies. }\end{array}$ \\
\hline
\end{tabular}

It is also appropriate to talk about the interdisciplinary approach to assess risks that are hidden behind the technological innovations use (digital transformation) while the development of the transhumanism trend, and the corresponding to this approach tools that impact on risks level. In this regard, a concept was developed based on this approach, that allows interconnecting different fields of knowledge in various spheres (Vorontsova \& Postigo Solana, 2019, p. 60).

In particular, one of these tools is bioethics (Vásquez Del Aguila \& Postigo Solana, 2015, pp. 507-508), whose impact on the risk level from using biotechnologies is limited by the acceptable risk zone. Also, actions related to human transformation should be evaluated from a position of their impact on the nearest events, realizing the consequences that they cause in the long term (Dugin, 2016).

The border between acceptable and critical risk zones is very thin, and in the case of the transhumanist approach, it has completely van- ished. This is why it is so important to follow moral and ethical principles when using new revolutionary technologies (Ortega y Gasset, 2004, pp. 743-746). However, in the human mind, not guided by Christian values, the moral aspect may be considered in different ways: what society does not accept today, will accept tomorrow, it is only necessary to give "reasonable" explanation (to open a discussion on this issue) and fix in people minds that this is normal, especially emphasizing the advantages from innovative technologies use.

Among other things, transhumanism opposes government initiatives that restrict and/or control advanced scientific researches and prohibit the use of such technologies as human cloning, mind uploading/downloading, isolated brain, and cryonics. These technologies are still at the development stage, but are already in the critical risk zone, keeping the tendency to move toward the catastrophic risk zone.

Applying ethical values (Cortina, 2019) will 
allow making decisions and monitoring the use of technological innovations based on their usefulness to achieve the desired economic result, on the one hand, and the well-being/health of people, on the other. Even well-known scientists draw the state's attention to the process of creating and developing advanced technologies (Morris, 2017) to determine the Rubicon in the race for super-profits from future technologies.

\section{Discussion}

The scientific novelty of authors research is the formation of conceptual and methodological provisions, as well as organizational, methodological and practical recommendations for applying the interdisciplinary approach to assess the risks of Smart technologies use in the context of the transhumanism global concept implementation. The directions of work with the risk expanse, which includes four zones, are presented. The main tools to assess the risk level in these zones, as well as their borders, have been identified.

\section{Conclusion}

Modern science is moving with ever-increasing speed. The proof of this is the transhumanism concept that is being realized by stage. One of these stages is presented by the digital economy, in which various Smart technologies are created and implemented. Transhumanism offers ways of further person improvement, forgetting about his/her human nature. It only suggests ways to solve immediate problems, but does not say in which direction to move, and what is the final goal of Being (based only on the materialistic point of view), leaving without answers the questions about meaning and ultimate purpose of human existence.

\section{Acknowledgement}

The results of the research were presented and discussed in the International forum "Transhumanism. Anthropological, ethical, legal and theological challenges" $30^{\text {th }}$ of May, 2019 in Madrid, Spain (University Pontificia Comillas ICAI-ICADE).

\section{REFERENCES}

Armstrong, S., Bradshaw, H., Beckstead, N., \& Sandberg, A. (2015). System Risk of Modelling in Insurance. Retrieved from https://tigerrisk.com/wp-content/uploads/2018/10/SystemicRisksofModellingFINALV3.pdf.

Bajo Sanjuán, A., \& Villagra García, N. (2017). Los retos de la globalización a la RSE: la revolución digital. Madrid, España: Universidad Pontificia Comillas ICAI ICADE.

Cortina, A. (2019). Libertad en la era digital. Retrieved from https://elpais.com/elpais/2019/02/25/opinion/1551096024_18 1754.html.

Diéguez, A. (2017).Transhumanismo. La búsqueda tecnológica del mejoramiento humano. Barcelona: Herder.

Diéguez, A. (2018). Transhumanismo y filosofia. El País. Retrieved from https://elpais.com/elpais/2018/09/12/opinion/153675 2872 112358.html.

Dugin, A. (2016). Transhumanismo. [Video message] Retrieved from https://www.geopolitica.ru/es/directives/transhumanismo.

Feltrero, R. (Ed.). (2018). Proceedings from Tec- 
nología e innovación social hacia un desarrollo inclusivo y sostenible. Madrid, España: Global Knowledge Academics.

Goldin, I., \& Mariathasan, M. (2014). The Butterfly Defect: How Globalization Creates Systemic Risk, and What to Do about It. Princeton University Press.

Humanity (2018). Transhumanist Declaration. Retrieved from https://humanityplus.org/philosophy/transhumanist-declaration/.

Morris, D. Z. (2017). Elon Musk Says Artificial Intelligence is the "Greatest Risk We Face as a Civilization". Retrieved from https://finance.yahoo.com/news/elonmusk-says-artificial-intelligence202534848.html?guccounter=1\&gucereferre$\mathrm{r}=\mathrm{aHR}$ 0cHM6Ly95YW5kZXgucnUv\&guce referrer sig=AQAAAJt2r6pXd 88pikbmgReJqA0UZqjiv2ZFr3ZkgJ1t NmmgcYbp-kTSRh8ZsCeNPmTx6M1HSw9Lw1o7autTYeR2EBMHkCUI NeOk-FdhZIPESjPzk Mx8-IzMhLbuSTpbA-xMjYw8g1qHF9vqshPo9eizB7W7kbbUuUSKn83FaMxSCWU.

Ortega y Gasset, J. (2004). Obras Completas. Madrid, España: Revista de Occidente. Postigo Solana, E. (2018). Transhumanismo, la nueva escena de un viejo argumento. Retrieved from https://www.academia.$\underline{\text { edu/38378554/Transhumanismolanuev }}$ aescenadeunviejo argumento.doc? $\mathrm{fs}=-$ rwc.

Sandberg, A. (2012) Gf 2045: Anders Sandberg. [Video message] Retrieved from https://yandex.ru/video/touch/search?fil $\underline{\text { mld }=12974653496765993043 \& \text { text }=\%}$
D0\%90\%D0\%BD\%D0\%B4\%D0\%B5

$\% \mathrm{D} 1 \% 80 \% \mathrm{D} 1 \% 81 \% 20 \% \mathrm{D} 1 \% 81 \% \mathrm{D} 0$ \%B0\%D0\%BD\%D0\%B4\%D0\%B1\% D0\%B5\%D1\%80\%D0\%B3\&noreask= $\underline{1 \& \text { path }=\text { wizard\&ts }=1573843519052 \&}$ source $=$ share.

Sandel, M. (2016). Contra la perfección: la ética en la era de la ingeniería genética. Barcelona: Marbot Ediciones.

Savulescu, J. (2012). ¿Decisiones peligrosas?: Una bioética desafiante. Tecnos: Science.

Terrones Rodrígues, A. L. (2019). Una aproximación general al transhumanismo $y$ su problematizeción. Retrieved from https://www.academia.edu/39615257/ Unaaproximacióngeneralaltranshumanismoysuproblematización?emailworkcard=view-paper.

Vásquez Del Aguila, J. W. \& Postigo Solana, E. (2015). Transhumanismo, neuroética y persona humana. Revista de Bioética. Retrieved from: https://www.academia.edu/38378808/Transhumanismoneur oéticaypersona.pdf

Vorontsova, Yu. V., \& Postigo Solana, E. (2019). Human Nature, Transhumanism and Digital Transformation. E-Management, 2(3), 58-63. doi:10.26425/2658-3445-2019-3-58-63

Yurchenco, T. I., \& Galyatkina, O. N. (2012). Instrumentarii obespecheniya ustoichivogo funkcionirovaniya organizacii (Tools for Providing Stable Functioning of Organization, in Russian). Vestnik Universiteta (State University of Management), 11(1), 215-221. 